\title{
Figures and Maps
}

1. The northern Atlantic of Juan de la Cosa (1500). 9

2. Excerpt from the St. Dié map of $15^{0} 7$ showing the narrow ocean between Africa and the New World.

3. Excerpt from the St. Dié map (1507) of the northern part of the New World.

4. Inset from the St. Dié map showing the New World as a continuous mainland from $50^{\circ} \mathrm{N}$ to $4^{\circ} \mathrm{S}$ latitude.

5. Route of Narváez in Florida.

6. Northern Atlantic portion of the Weimar map of 1527 .

7. Northern Atlantic portion of the RibeiroWolfenbüttel map of $\mathbf{1 5 3 2}$.

8. The Sea Island coast of the Ayllón colony. $\quad 73$

9. The Cartier voyages.

10. Route of the Cabeza de Vaca party. 118

11. Route of Coronado to Cibola. 135

12. Palo Duro Canyon south of Amarillo, Texas. 144

13. Woodcut of an American bison (1554). 149

14. Route of the De Soto party. 164

15. The Sea Islands in the French-Spanish conflict. 198

16. East coast of Florida during the French-Spanish confrontation.

17. De Bry's version of the French landing at Port Royal (1590). 
18. Indians planting corn as pictured by de Bry (1590).

19. A Timucua village according to de Bry (1590). 210

20. The Jesuit mission to Powhatan country (in Virginia).

21. Water color map of Albemarle and Pamlico sounds by John White.

255

22. John White's sketch of the Indian village of Pomeiooc.

262

23. John White's water color of the Indian village of Secotan. 